Review: Distribution of Agricultural Products and Live Stock outside the Tropics Author(s): A. J. Herbertson

Review by: A. J. Herbertson

Source: The Geographical Journal, Vol. 15, No. 1 (Jan., 1900), pp. 52-55

Published by: geographicalj

Stable URL: http://www.jstor.org/stable/1774881

Accessed: 27-06-2016 18:02 UTC

Your use of the JSTOR archive indicates your acceptance of the Terms \& Conditions of Use, available at

http://about.jstor.org/terms

JSTOR is a not-for-profit service that helps scholars, researchers, and students discover, use, and build upon a wide range of content in a trusted digital archive. We use information technology and tools to increase productivity and facilitate new forms of scholarship. For more information about JSTOR, please contact support@jstor.org.

The Royal Geographical Society (with the Institute of British Geographers), Wiley are collaborating with JSTOR to digitize, preserve and extend access to The Geographical Journal 
keep straight on. Arrived at length in the narrow, thickly wooded valley of the Omo, the travellers turned at once towards its mouth, and succeeded in eluding their dangerous neighbours. Leaving the river for a time, they had to fight their way through the mountains, inhabited, for the first time, by tribes of negroid character. Again reaching the Omo on its exit from the mountains, the expedition followed down its eastern bank-round the great northerly curve, which seems to have led Dr. Donaldson Smith to mistake a tributary for the main stream-until at last the sight of Lake Rudolf told the travellers that their chief task was accomplished.

Although the chapters which tell of the march through the Alpine regions of East Africa are perhaps the most interesting part of the book, the subsequent portion, dealing with the exploration of the headstreams of the Sobat and the ascent to the Abyssinian plateau, is of scarcely less importance. The main narrative is followed by extracts from a journal kept by Dr. Sacchi on his fatal attempt to reach the coast from Lake Rudolf, with a map of his itinerary through the Boran country east of Lake Stefanie. The results of the surveys carried out during the whole march are shown on five large-scale sectional maps, based on 132 observations for latitude and 63 for longitude, which are fully discussed by Prof. Millosevich in an appendix. Other appendices give the scientific results of the expedition in other directions, which, valuable as they are, would have been still more complete had it not been for the loss of a part of the notes during the attack on the party near the Abyssinian frontier. The sections dealing with meteorology and geology, the latter illustrated by a special map based on the collections of Dr. Sacchi, are of particular value. The whole of the Alpine region of Lake Margherita and the Omo falls within the area of recent volcanic racks, while in the Juba valley older volcanic rocks with calcareous and cretaceous strata of Mesozoic age are largely developed.

\section{DISTRIBUTION OF AGRICULTURAL PRODUCTS AND LIVE STOCK OUTSIDE THE TROPICS.*}

By A. J. HERBERTSON, D.Sc.

THE botanist who studies the distribution of plants usually eliminates all consideration of the plants cultivated by man, as vitiating his inquiry'. The present work is an elaborate study, based on statistics, of the distribution of cultivated plants, and is the first complete work of its kind.

* 'Die Landbauzonen der aussertropischen Länder.' Auf Grund der statistischen Quellenwerke dargestellt von 'Th. H. Engelbrecht. In three volumes: vol. i. Text; pp. xi., 279; vol. ii., Statistics, pp. x., 383; vol. iii., Atlas, pp, viii., 79 maps. Berlin. 1899. Dietrich Reimer (Ernst Vohsen). 
Originally inspired by the increase of American cereals in European markets twenty years ago, and planned as a study of the crops in the two continents, the work has been extended to include all the crops and live stock of the great cereal-producing regions of the World outside the tropics. The statistics are, in the first place, those for 1882 for most European countries, but they are compared with both earlier and more recent statistics in most countries, so that the second volume, which includes the statistical tables, is a most valuable source of accurate information as to the area growing cereals and the number of live stock, not merely in comparatively recent years, but also in the past.

The fault we find with the statistics is that for most countries single years have been taken. In the case of Argentina, for instance, the fluctuations from year to year in the wheat-producing area are so great that a comparison of one pair of years would lead to apparently diametrically opposite conclusions from that of another pair of years. In a work of this magnitude the mean values should have been calculated for a series of years. This would no doubt have involved much labour, but it would have given a greater and more lasting value to the elaborate maps which form the third part of the work.

The author has not shirked labour, for he has expressed the statistics in relative as well as in absolute figures. He has chosen what seems to us very unfortunate standards of comparison-in the case of agricultural products, the area sown with cereals (Halmgetreide, the northern cereals, excluding the Hackgetreide, the tropical cereals, such as maize and rice); in the case of live stock, the number of cattle. The former are useful in showing the relative importance of any particular crop compared with the total cereal crop in any region, but they give no indication of the relative importance of the particular crop in different regions, which is by far the most important consideration for geographical purposes. It is greatly to be regretted that the author should have considered the plan of the statistics to the common denominator of the total area of each region only to dismiss it. This is by far the most satisfactory method of treatment for cartographic purposes, except in cases where the data and the scale of the maps permit the delimitation of uncultivated lands, when the arable area can be used as the common denominator in the case of agricultural products, and the results of the calculations shown over only the arable region, and not over the whole political region of which it forms part.

'The author's method leads to emphasizing the less of two important considerations, the one which can be most easily appreciated by a comparison of a series of maps. His maps show that in 1882, with hardly an exception, more than half the cereal-producing land of Scotland, Wales, and Ireland was cultivated for oats, and that in Suffolk less than 10 per cent. of this land was so utilized. This is useful if we have a map showing that in, say, Ross and Cromarty 2 per cent., and in Suffolk 
37 per cent., of the total area produced cereals, as happened on the average from 1891 to 1895 . He gives no such map. He does not even give the statistics that would have permitted the calculation of data from which such a map could be constructed, although it would have been easy to add a row of areas, at least in most countries dealt with. One has to obtain such statistics from other sources to discover that the same proportions of the surface of Ross and Cromarty and of Suffolk are sown with oats, namely 1.7 per cent., for in the former county $64 \cdot 7$, and in the latter only $5 \cdot 2$, per cent. of land growing cereals yielded oats. The author would say that the map based on proportion of total area growing oats would indicate that oats were more important in Suffolk than Ross and Cromarty, and would conceal the fact that they were by far the most important cereal in the latter county. Surely a comparison of wheat, barley, and oat maps would at once indicate this fact. The method of first eliminating, both in statistical tables and on the map, the uncultivated area would overcome this difficulty, and permit both the facts of the northern county having few crops and those chiefly oats, to be illustrated on one map. As it is, we have no means of appreciating from the atlas the intensity of cultivation of any particular crop in different regions. This would have been possible, had Mr. Engelbrecht calculated and depicted for each region the proportion of its cereal-producing land to the whole, and the number of cattle per unit area, by comparing such maps with those showing the relative proportion of one cereal crop to all, and of other live stock to cattle. It would be, however, much more difficult to obtain all the different interpretations of the facts from such a series of maps than from the other series, where everything was expressed in terms of the total area.

Although we think the relative tables and the maps would have been more useful if treated differently, yet the great excellence of all parts of this monumental work must not be overlooked. The tables are full of invaluable figures, the text of important observations, and the maps reveal many interesting features of distribution. Some of the maps, showing the distribution of two different crops, e.g. wheat and sugar in Australia, those with lines showing regions where wheat predominates over rye in Europe, are most instructive. Innumerable relationships are discussed in the text between climate and crops, and between one crop and other plants, and some of these are illustrated in the atlas.

On numerous maps selected isotherms are drawn, and in many cases these run close to the boundary of cultivation. For instance, hardly any maize is grown in Europe where the mean temperature is under $19^{\circ}$ C. in June, in Australia where under $18^{\circ} \mathrm{C}$. in January, but in North America maize is grown in all of the United States, in many of which the mean temperature in June is lower than this. In the case of Australia, especially, some rainfall lines would have proved valuable 
addition, e.g. that of 15 inches per annum, outside of which little wheat can be grown; and 30 inches, which approximately forms the western limit of maize in the east; and 40 inches, which bounds the region of more intensive maize cultivation. The increase of goats, mules, and asses in the drier areas is graphically shown on the maps, and would have been made clearer by a series of isohyets.

On many of the maps the distribution of a number of forest trees is indicated and correlated with that of the cultivated plants. This we consider a most valuable feature of the work. For instance, noting that the northern limits of the cultivation of oats almost coincides with that of the breaking buckthorn (Rhamnus frangula, L.) in European Asia, that its southern limit is almost coincident with the southern limits of the bird cherry (Prunus padus, L.), we may assume that the region between the natural limits of the growth of these trees in Siberia is a possible area for oat culture, and beyond that it would probably fail.

From a geographical point of view, the study of plant associations is more important than the study of the distribution of an individual species, and has great economic possibilities, so much so that in recent years special surveys of natural biological conditions have been started in several of the American states for the benefit of the farmer. This plan of comparing the distribution of cultivated plants with that of natural plants may be looked on as a special and most valuable application of the method. In this way it becomes possible to say, from the study of the natural flora, what the chances of success in cultivating special economic plants will be.

Two other valuable features of this great work must be noted: (1) There is a discussion of changes in the intensity of cultivation in the past fow decades, of which the diminution of wheat in our own country and the increase of wheat in the more recently settled lands of the globe is the most striking example; but the retreat of the polar limits of wheat, the vine, and cotton with the increase of transport facilities is quite as interesting, if less known. (2) The first map and part of the introductory text deals with the different extra-tropical cultivation belts, which Mr. Engelbrecht divides into (a) arctic, (b) arctic and antarctic barley belts, $(c)$ the oat belts, $(d)$ the steppes of Central Asia and Southern Russia, $(e)$ the maize belts, $(f)$ the sub-tropical barley belt, $(g)$ the sub-tropical cotton belt, and $(h)$ the sub-tropical sugar-cane belt. 